Article

\title{
Carbonylative Suzuki coupling reactions of aryl iodides with arylboronic acids over $\mathrm{Pd} / \mathrm{SiC}$
}

\author{
Yanli Cui a,b, Xiaoning Guo ${ }^{\text {a,* }}$, Yingyong Wang a , Xiangyun Guo ${ }^{\text {a }}$ \\ a State Key Laboratory of Coal Conversion, Institute of Coal Chemistry, Chinese Academy of Sciences, Taiyuan 030001, Shanxi, China \\ b University of Chinese Academy of Sciences, Beijing 100049, China
}

A R T I C L E I N F 0

Article history:

Received 14 September 2014

Accepted 28 November 2014

Published 20 March 2015

\section{Keywords:}

Palladium/silicon carbide

Carbonylation Suzuki coupling

Aryl iodide

Arylboronic acid

Heterogeneous catalysis

\begin{abstract}
A B S T R A C T
High surface area $\mathrm{SiC}$ has been used to prepare a Pd/SiC catalyst using the liquid reduction method, and the resulting catalyst was used for the carbonylative Suzuki coupling reaction of aryl iodides with arylboronic acids. The catalyst was also characterized by X-ray diffraction, inductively coupled plasma-mass spectroscopy and high-resolution transmission electron microscopy. The results of these analyses showed that homogeneous Pd nanoparticles with a mean diameter of $2.8 \mathrm{~nm}$ were uniformly dispersed on the $\mathrm{SiC}$ surface. Optimization of the reaction conditions for the carbonylative Suzuki coupling reaction, including the solvent, base, pressure, temperature and reaction time, revealed that the model reaction of iodobenzene $(1.0 \mathrm{mmol})$ with phenylboronic acid $(1.5 \mathrm{mmol})$ could reach $90 \%$ conversion with a selectivity of $99 \%$ towards the diphenyl ketone using $3 \mathrm{wt} \%$ $\mathrm{Pd} / \mathrm{SiC}$ under $1.0 \mathrm{MPa}$ of $\mathrm{CO}$ pressure at $100{ }^{\circ} \mathrm{C}$ for $8 \mathrm{~h}$ with $\mathrm{K}_{2} \mathrm{CO}_{3}(3.0 \mathrm{mmol})$ as the base and anisole as the solvent. The $\mathrm{Pd} / \mathrm{SiC}$ catalyst exhibited broad substrate scope towards the carbonylative Suzuki coupling reaction of aryl iodides with arylboronic acids bearing a variety of different substituents. Furthermore, the $\mathrm{Pd} / \mathrm{SiC}$ catalyst exhibited good recyclability properties and could be recovered and reused up to five times with the conversion of iodobenzene decreasing only slightly from $90 \%$ to $76 \%$. The decrease in the catalytic activity after five rounds was attributed to the loss of active Pd during the organic reaction.
\end{abstract}

(C) 2015, Dalian Institute of Chemical Physics, Chinese Academy of Sciences. Published by Elsevier B.V. All rights reserved.

\section{Introduction}

Aromatic ketones are important building blocks in organic chemistry, and compounds belonging to this structural class can be found in a wide variety of biologically active natural products and pharmaceutical molecules [1,2]. In light of their importance and general utility, various methods have been reported for the preparation of aromatic ketones. Traditional synthetic routes for the construction of aromatic ketones include the Friedel-Crafts acylation of aromatic compounds with acyl halides [3] and the transition-metal-catalyzed cross-coupling reactions of aryl metal reagents such as $\mathrm{C}_{6} \mathrm{H}_{5} \mathrm{MgBr}$ [4] and $\mathrm{C}_{6} \mathrm{H}_{5} \mathrm{SiF}_{n} \mathrm{Me}_{3-n}$ [5] with carbon monoxide and a suitable electrophile [6]. However, the former of these two reactions requires the addition of a large excess of Lewis acid and is incompatible with many functional groups $[3,7,8]$, whereas the latter usually results in the formation of biphenyl byproducts.

In 1993, Suzuki's group [9] reported a direct method (i.e., the carbonylative Suzuki coupling reaction) for the synthesis of aromatic ketones by the reaction of $\mathrm{CO}$ with an aryl halide and

\footnotetext{
*Corresponding author. Tel/Fax: +86-351-4040468; E-mail: guoxiaoning@sxicc.ac.cn This work was supported by the National Natural Science Foundation of China (21203233) and the Natural Science Foundation of Shanxi Province (2013021007-1).

DOI: 10.1016/S1872-2067(14)60258-8 | http://www.sciencedirect.com/science/journal/18722067 | Chin. J. Catal., Vol. 36, No. 3, March 2015
} 
arylboronic acid in the presence of $\mathrm{PdCl}_{2}$ and $\mathrm{Pd}(\mathrm{dba})_{2}$ (bis(dibenzylideneacetone)palladium). This reaction provides a versatile platform for the direct synthesis of aromatic ketones using boronic acids, which are generally non-toxic and stable to air and moisture. Ishiyama et al. [10] used a variety of different catalysts to affect this carbonylative Suzuki reaction, including $\mathrm{PdCl}_{2}\left(\mathrm{PPh}_{3}\right)_{2}$ and $\mathrm{PdCl}_{2}$ (dppf)([1,1'-bis(diphenylphosphino) ferrocene]dichloropalladium(II)). However, the conversion and selectivity of these reactions are low and require the presence of a ligand to proceed effectively. Khedkar et al. [11] reported that immobilized palladium ion-containing ionic liquids exhibited excellent catalytic activity towards the carbonylative Suzuki coupling reaction of aryl halides with arylboronic acids, with the coupled products being isolated in high yields. However, the overall utility of this process is limited by its requirement for the use toxic organic compounds, which are harmful to the environment. Niu et al. [12] reported the stabilization of Pd on hollow magnetic mesoporous spheres and the use of this material as a heterogeneous catalysis for the carbonylative Suzuki coupling reaction. However, the preparation of this catalyst is complex. Therefore, despite good progress during the last 20 years towards the development of robust methods for the preparation of aromatic ketones, the high costs associated with the preparation of complex catalysts and ligands, and the difficulties involved in the separation of catalysts from the reaction mixture have greatly limited the application and development of the carbonylative Suzuki coupling reaction. Based on these limitations, there is still considerable scope for exploring the development of new stable and efficient heterogeneous catalysts for the carbonylative Suzuki coupling reaction.

$\mathrm{SiC}$ has excellent chemical stability and thermal conductivity properties, and has been successfully used as catalyst support in various catalytic reactions, including the oxidation of $\mathrm{CO}$ [13], reforming of $\mathrm{CH}_{4}$ and $\mathrm{CO}_{2}[14,15]$, photocatalytic water splitting [16], methanation [17] and the photocatalytic reduction of $\mathrm{CO}_{2}$ [18]. We recently reported that SiC-supported Pd nanoparticles significantly enhanced the hydrogenation of furan derivatives under low temperature $\left(25^{\circ} \mathrm{C}\right)$ and low pressure (1.0 MPa of $\mathrm{H}_{2}$ ) conditions by visible light irradiation [19]. Notably, the yield of tetrahydrofuran from the hydrogenation of furan under these conditions was $99 \%$ with a turnover frequency of $70 \mathrm{~h}^{-1}$. In this study, a Pd/SiC catalyst has been prepared by a liquid reduction method using high surface area $\mathrm{SiC}$ as a support, and investigated its catalytic performance towards the carbonylative Suzuki coupling reaction under heterogeneous conditions.

\section{Experimental}

\subsection{Preparation and characterization of $\mathrm{Pd} / \mathrm{SiC}$}

The Pd/SiC catalyst (3 wt\%) was prepared using a liquid phase reduction method. Palladium nitrate $(132.6 \mathrm{mg}, 0.564$ $\mathrm{mmol}$ ) and $\mathrm{SiC}$ powder (1.94 $\mathrm{g}, S_{\mathrm{BET}}=50 \mathrm{~m}^{2} / \mathrm{g}$ ) were dispersed in absolute ethanol (50 $\mathrm{mL})$ under sonication conditions, and the resulting suspension was magnetically stirred to get a homogenous mixture of palladium nitrate and SiC. The mixture was dispersed in $80 \mathrm{~mL}$ of diethylene glycol (DEG), and the resulting suspension was heated to $140{ }^{\circ} \mathrm{C}$ for $30 \mathrm{~min}$. Water (2.5 $\mathrm{mL})$ was then added to the reaction, and the resulting mixture was reduced for $2 \mathrm{~h}$ at $180{ }^{\circ} \mathrm{C}$ to give the $3 \mathrm{wt} \% \mathrm{Pd} / \mathrm{SiC}$ catalyst.

The Pd content of the catalyst was determined by inductively coupled plasma (ICP) atomic emission spectrometry using an Atomscan 16 system (Thermo Fisher Scientific, Shanghai, China). The phase characterization of the catalyst was determined using a Rigaku D-Max/RB X-ray diffraction (XRD) system (Tokyo, Japan) using $\mathrm{Cu}-K_{\alpha}$ radiation. The structure and morphology of the catalyst were characterized by transmission electron microscopy (TEM) using a JEM-2100F system (JEOL, Tokyo, Japan). X-ray photoelectron spectroscopy (XPS) measurements were conducted on an ESCALAB 3 MKII de VG spectrometer (VG Scientific, East Sussex, United Kingdom) using Mg $K_{\alpha}(15 \mathrm{kV}, 20 \mathrm{~mA})$ as an X-ray source.

\subsection{Carbonylative Suzuki coupling reactions}

All of the carbonylative Suzuki coupling reactions were conducted in a sealed stainless steel reaction kettle. Arylboronic acid (1.5 mmol), aryl iodide $(1.0 \mathrm{mmol})$, base $(3.0$ $\mathrm{mmol}), 3 \mathrm{wt} \% \mathrm{Pd} / \mathrm{SiC}$ and anisole $(10 \mathrm{~mL})$ were added to the reaction kettle, and the resulting mixture was placed under a certain pressure of $\mathrm{CO}$. All of the reactions were conducted over several hours at certain temperatures. The products of the reactions were analyzed by GC-MS on a Bruker SCION SQ 456 GC-MS system (Karlsruhe, Germany).

\section{Results and discussion}

\subsection{Morphology and structure of the Pd/SiC catalyst}

The Pd loading of the $\mathrm{Pd} / \mathrm{SiC}$ catalyst was determined to be $2.91 \mathrm{wt} \%$ by ICP-MS analysis, which is similar to the calculated value. BET analysis showed that the surface area of the $\mathrm{Pd} / \mathrm{SiC}$ catalyst was $56 \mathrm{~m}^{2} / \mathrm{g}$. The TEM images of the $\mathrm{Pd} / \mathrm{SiC}$ catalyst (Fig. 1) showed that homogeneous metallic Pd nanoparticles were uniformly dispersed on the $\mathrm{SiC}$ surface with a narrow size distribution of 1-5 $\mathrm{nm}$ and a mean diameter of $2.8 \mathrm{~nm}$. The lattice fringe of the nanoparticles had an interplanar spacing of $0.19 \mathrm{~nm}$, which was in agreement with the (200) plane of Pd. The XRD pattern of the Pd/SiC catalyst (Fig. 2) showed that all of the strong diffraction peaks could be indexed to $\beta$-SiC. The

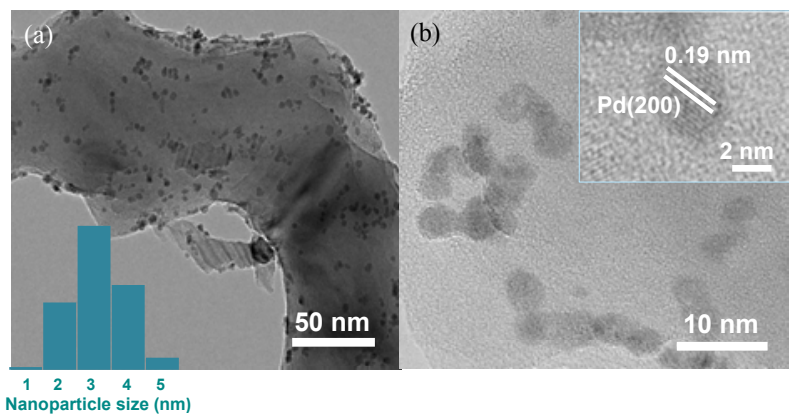

Fig. 1. TEM and HRTEM images (inset of (b)) of Pd/SiC catalyst, and the size distribution of Pd nanoparticles (inset of (a)). 


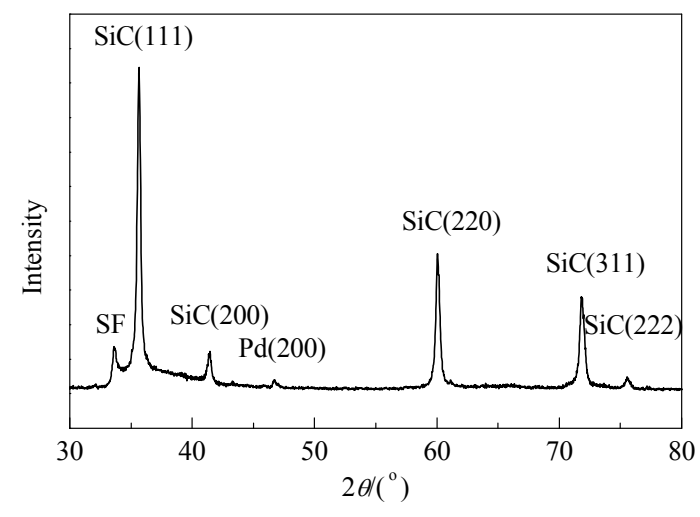

Fig. 2. XRD pattern of the $\mathrm{Pd} / \mathrm{SiC}$ catalyst.

diffraction peaks at $2 \theta=33.6^{\circ}$ and $46.7^{\circ}$ were attributed to stacking faults and cubic Pd, respectively.

\subsection{Effect of reaction conditions}

The effects of various reaction parameters, including the solvent, base, temperature, time and CO pressure, were investigated for the reaction of iodobenzene with phenylboronic acid, and the results are summarized in Table 1 . Several different bases, including $\mathrm{K}_{2} \mathrm{CO}_{3}, \mathrm{Cs}_{2} \mathrm{CO}_{3}$ and $\mathrm{Na}_{2} \mathrm{CO}_{3}$, were investigated in toluene at $100{ }^{\circ} \mathrm{C}$ under $0.5 \mathrm{MPa}$ of CO pressure over 5 $\mathrm{h}$ (Table 1, entries 1-3). The iodobenzene conversion in these three cases were found to be $51 \%, 10 \%$ and $42 \%$, respectively, with selectivity towards the diphenyl ketone of $93 \%, 91 \%$ and $90 \%$, respectively, which suggested that the nature of the base was having a significant impact of the outcome of the reaction. Because $\mathrm{K}_{2} \mathrm{CO}_{3}$ gave the highest conversion, it was selected as the optimal base for the remaining optimization reactions. When anisole was used instead of toluene as the reaction solvent (Table 1, entry 4), the conversion of iodobenzene and selectivity towards diphenyl ketone reached $62 \%$ and $98 \%$, re-

\section{Table 1}

The catalytic performance of $\mathrm{Pd} / \mathrm{SiC}$ for carbonylative Suzuki coupling reaction of iodobenzene with phenylboronic acid under different reaction conditions a.

\begin{tabular}{llcccccc}
\hline Entry & Solvent & Base & $p / \mathrm{MPa}$ & $T /{ }^{\circ} \mathrm{C}$ & $t / \mathrm{h}$ & $C / \%$ & $S / \%$ \\
\hline 1 & Toluene & $\mathrm{K}_{2} \mathrm{CO}_{3}$ & 0.5 & 100 & 5 & 51 & 93 \\
2 & Toluene & $\mathrm{Cs}_{2} \mathrm{CO}_{3}$ & 0.5 & 100 & 5 & 10 & 91 \\
3 & Toluene & $\mathrm{Na}_{2} \mathrm{CO}_{3}$ & 0.5 & 100 & 5 & 42 & 90 \\
4 & Anisole & $\mathrm{K}_{2} \mathrm{CO}_{3}$ & 0.5 & 100 & 5 & 62 & 98 \\
5 & Anisole & $\mathrm{K}_{2} \mathrm{CO}_{3}$ & 0.5 & 80 & 5 & 21 & 95 \\
6 & Anisole & $\mathrm{K}_{2} \mathrm{CO}_{3}$ & 0.5 & 120 & 5 & 78 & 93 \\
7 & Anisole & $\mathrm{K}_{2} \mathrm{CO}_{3}$ & 0.5 & 100 & 8 & 74 & 97 \\
8 & Anisole & $\mathrm{K}_{2} \mathrm{CO}_{3}$ & 1.0 & 100 & 8 & 90 & 99 \\
9 b & Anisole & $\mathrm{K}_{2} \mathrm{CO}_{3}$ & 1.0 & 100 & 8 & 17 & 96 \\
$10^{c}$ & Anisole & $\mathrm{K}_{2} \mathrm{CO}_{3}$ & 1.0 & 100 & 8 & 29 & 94 \\
\hline
\end{tabular}

Reaction conditions: (a) A mixture of iodobenzene (1.0 mmol), phenylboronic acid $(1.5 \mathrm{mmol})$, base $(3.0 \mathrm{mmol})$ and $3 \mathrm{wt} \% \mathrm{Pd} / \mathrm{SiC}(50 \mathrm{mg}$, containing $0.014 \mathrm{mmol} \mathrm{Pd})$ in solvent $(10 \mathrm{~mL})$ was heated at a specific temperature under a certain pressure of $\mathrm{CO}$ for a specific time; (b) pure $\mathrm{SiC}(50 \mathrm{mg})$ was used as the catalyst; $(\mathrm{c}) \mathrm{Pd}\left(\mathrm{NO}_{3}\right)_{2}$ (3.2 mg, containing $0.014 \mathrm{mmol}$ Pd) was used as the catalyst.

Note: $p=$ pressure, $T=$ temperature, $t=$ time, $C=$ conversion and $S=$ selectivity. Calculations for conversion and selectivity are based on iodobenzene. spectively, which are higher than the values achieved using toluene as solvent. Taken together with the fact that toluene is more toxic than anisole, the latter of these two solvents was chosen as the optimal solvent for the reaction system.

An increase in the reaction temperature led to an increase in the conversion of iodobenzene (Table 1, entries 4-6). When the temperature was increased from 100 to $120^{\circ} \mathrm{C}$, the conversion increased from $62 \%$ to $78 \%$, although the selectivity towards the diphenyl ketone decreased slightly from $98 \%$ to $93 \%$. The use of higher temperatures can lead to an increase in the quantity of adsorbed reactant molecules in the excited states, as dictated by the Bose-Einstein distribution, which means that the reactant molecules then require less energy to overcome the reaction barrier. However, side reactions leading to the formation of biphenyl also occur much more readily at higher temperatures, leading to a decrease in selectivity towards the diphenyl ketone. Increasing the CO pressure can lead to an increase in the number of $\mathrm{CO}$ molecules being absorbed and activated by the active sites of the Pd catalyst, and this effect led to an improvement in the catalytic activity of the $\mathrm{Pd} / \mathrm{SiC}$ catalyst (Table 1, entry 8). In the same way, extending the reaction time led to an increase in the conversion of iodobenzene (Table 1, entries 7 and 8). Taken together, the results of these optimization reactions revealed that iodobenzene conversion and diphenyl selectivity values of $90 \%$ and $99 \%$, respectively, could be achieved using anisole as a solvent and $\mathrm{K}_{2} \mathrm{CO}_{3}$ as a base under $1.0 \mathrm{MPa}$ of $\mathrm{CO}$ pressure at $100{ }^{\circ} \mathrm{C}$ following a reaction time of $8 \mathrm{~h}$ (Table 1 , entry 8 ).

Control experiments using only pure $\mathrm{SiC}$ or $\mathrm{Pd}\left(\mathrm{NO}_{3}\right)_{2}$ instead of the $\mathrm{Pd} / \mathrm{SiC}$ catalyst were conducted in the absence of a ligand under the optimized conditions and gave iodobenzene conversion values of only $27 \%$ and $29 \%$, respectively (Table 1 , entries 9 and 10). These results indicated that metallic Pd was involved as the active phase for this reaction and therefore critical to a high level of conversion. The rate of carbonylative Suzuki coupling reaction between an aryl iodide and an arylboronic acid is usually slow, whereas the self-coupling of arylboronic acids generally occurs at a much faster rate. With this in mind, the stoichiometry of the reaction was fixed with a significant excess of the phenylboronic acid ( $1.5 \mathrm{mmol}$ ) relative to the iodobenzene $(1.0 \mathrm{mmol})$ to achieve the highest possible level of iodobenzene conversion. It was envisaged that the excess arylboronic acid would form the corresponding biphenyl.

A hot filtration experiment was conducted to further confirm the active phase of the catalyst. Briefly, the $\mathrm{Pd} / \mathrm{SiC}$ catalyst was separated from the reaction system by hot filtration after the reaction had proceeded for $4 \mathrm{~h}$ with a $51 \%$ conversion of iodobenzene, and the resulting filtrate was allowed to react under the same reaction conditions in the absence of the $\mathrm{Pd} / \mathrm{SiC}$ catalyst for $4 \mathrm{~h}$. The results of this experiment showed that there was no change in iodobenzene conversion, which provided further confirmation that metallic Pd nanoparticles were performing as the active phase in the current carbonylative Suzuki reaction.

Based on these results, the optimized reaction conditions were determined to be as follows: iodobenzene $(1.0 \mathrm{mmol})$, phenylboronic acid (1.5 mmol) and $\mathrm{K}_{2} \mathrm{CO}_{3}(3.0 \mathrm{mmol})$ in anisole 
(10 mL). The reaction was catalyzed by $3 w t \% \mathrm{Pd} / \mathrm{SiC}$ at $100{ }^{\circ} \mathrm{C}$ and 1.0 MPa of CO pressure for $8 \mathrm{~h}$. The optimized conditions (Table 2, entry 1) gave an iodobenzene conversion of $90 \%$ with a selectivity towards diphenyl ketone of $99 \%$.

\subsection{Catalytic performance of Pd/SiC for different aryl iodides with arylboronic acids}

To test the general applicability of our newly developed $\mathrm{Pd} / \mathrm{SiC}$ catalyst, we evaluated its performance as a catalyst towards the reaction of a wide range of aryl iodides and arylboronic acids bearing various different substituents. The results of these experiments are summarized in Table 2, and show that the $\mathrm{Pd} / \mathrm{SiC}$ catalyst exhibited excellent activity towards a wide range of different substrates.

The presence of an electron-withdrawing group on the aryl iodide, such as a $\mathrm{NO}_{2}, \mathrm{CN}, \mathrm{Ac}$ or $\mathrm{Cl}$ group, greatly improved the reaction conversion (Table 2 , entries 2-5). In contrast, the presence of an electron-donating group on the aryl iodide, such as an $\mathrm{NH}_{2}$, Me or OMe group, led to a decrease in the conversion compared with iodobenzene (Table 2, entries 6-8). This difference in the reactivity patterns of the aryl iodide substrates was attributed to the electron-withdrawing group effectively enhancing the rate of the nucleophilic substitution reaction. The carbonylative Suzuki coupling reactions of iodobenzene with 4-methoxybenzeneboronic acid and 4-t-butylphenylboronic acid proceeded smoothly to give the corresponding products in high yields of $82 \%$ and $88 \%$, respectively (Table 2 , entries 9 and 10).

Pleasingly, the reaction was found to be amenable to scale-up and the Pd/SiC catalyst exhibited good catalytic activity when it was scaled-up 10-fold (i.e., $10.0 \mathrm{mmol}$ aryl iodide, $15.0 \mathrm{mmol}$ arylboronic acid, $30.0 \mathrm{mmol} \mathrm{K}_{2} \mathrm{CO}_{3}$ and $500 \mathrm{mg}$ of 3 wt $\% \mathrm{Pd} / \mathrm{SiC}$ in $100 \mathrm{~mL}$ of anisole under $1.0 \mathrm{MPa}$ of $\mathrm{CO}$ and 100 ${ }^{\circ} \mathrm{C}$ for $8 \mathrm{~h}$ ). For example, the conversion of iodobenzene, $p$-iodonitrobenzene and $p$-iodotoluene were found to be $87 \%$, $95 \%$ and $79 \%$, respectively, at the larger scale and the selectivity towards the corresponding aromatic ketones was 99\% in all three cases.

Besides aryl iodides, the $\mathrm{Pd} / \mathrm{SiC}$ catalyst also catalyzed the carbonylative Suzuki coupling reactions of several aryl bromides or chlorobenzene with phenylboronic acid to produce the corresponding aromatic ketones. Unsurprisingly, however, the $\mathrm{Pd} / \mathrm{SiC}$ catalyst showed lower activity towards the aryl bromides or chlorobenzene than it did towards iodobenzene because of their low reactivity (Table 2, entries 11-14).

\subsection{The stability of Pd/SiC catalyst}

Good recyclability is a highly desirable property for an effective heterogeneous catalyst. To test the recyclability of the $\mathrm{Pd} / \mathrm{SiC}$ catalyst towards the carbonylative Suzuki coupling reaction of iodobenzene and phenylboronic acid, the catalyst was reused five times after being filtered from a completed reaction and dried. A decrease in the activity of the catalyst was found after five reaction cycles, with the conversion decreasing from $90 \%$ for the first cycle to $76 \%$ at the fifth cycle (Fig. 3(a)). Analysis of the used catalyst by TEM did not reveal any obvious changes in the morphology or aggregation of the Pd nanoparticles (Fig. 3(b)). The binding energy (BE) values of metallic Pd

Table 2

Performance of the $\mathrm{Pd} / \mathrm{SiC}$ catalyst for the carbonylative Suzuki coupling reaction of various aryl halides with arylboronic acids bearing different substituents.

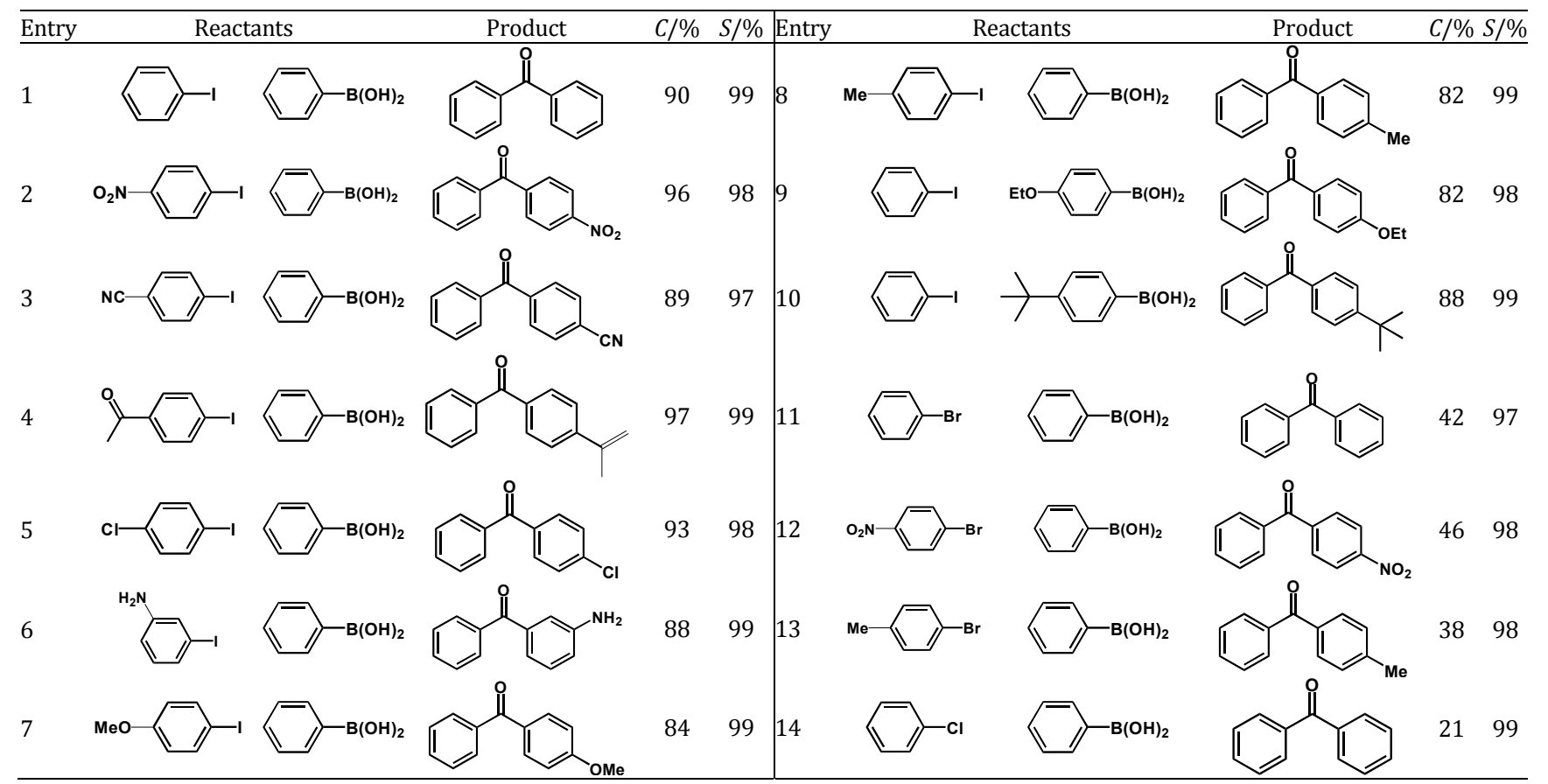

Reaction conditions: A mixture of aryl halide (1.0 mmol), arylboronic acid (1.0 mmol), $\mathrm{K}_{2} \mathrm{CO}_{3}(3.0 \mathrm{mmol})$ and $3 \mathrm{wt} \% \mathrm{Pd} / \mathrm{SiC}(50 \mathrm{mg}) \mathrm{in}$ anisole $(100$ $\mathrm{mL}$ ) was heated at $80^{\circ} \mathrm{C}$ under $1.0 \mathrm{MPa}$ of $\mathrm{CO}$ pressure for $8 \mathrm{~h}$. The conversion caculation and selectivity calculation are based on the amount of iodobenzene. 

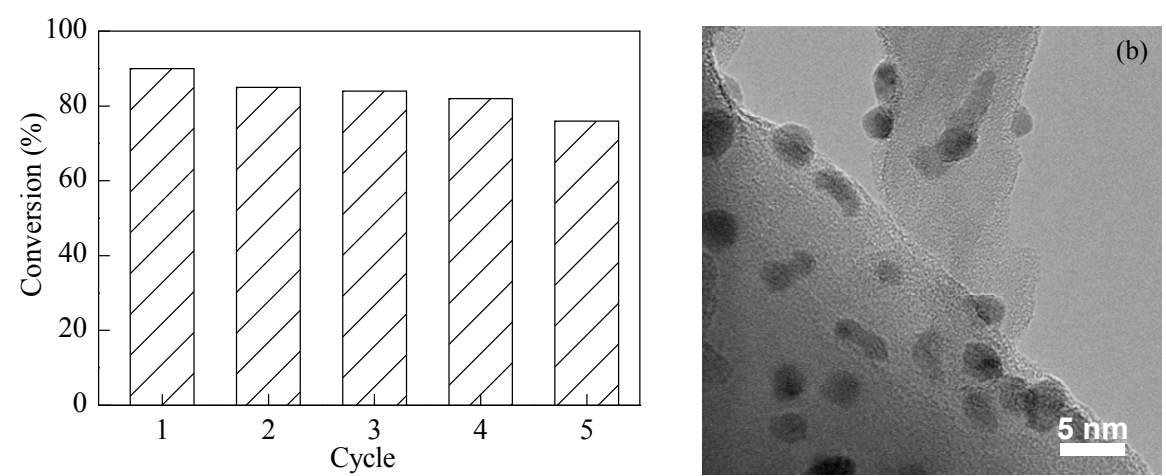

Fig. 3. Catalytic stability of the Pd/SiC catalyst for the carbonylative Suzuki coupling reaction of iodobenzene with phenylboronic acid (a), and TEM image of the catalyst after the fifth catalytic cycle (b).

are generally in the range of $334.7-335.5 \mathrm{eV}$ for $\mathrm{Pd} 3 d_{5 / 2}$ and 340.3-340.8 eV for Pd 3d3/2. Analysis of the used Pd/SiC catalyst by XPS revealed that the Pd nanoparticles were still metallic after the fifth reaction cycle (Fig. 4). However, the results of ICP-MS analysis revealed that the Pd loading of the Pd/SiC catalyst had decreased from $2.91 \%$ to $2.37 \%$ after the fifth reaction cycle, which indicated that the loss of the active Pd phase from the $\mathrm{Pd} / \mathrm{SiC}$ catalyst during the reaction process was the main reason for the observed decrease in the conversion.

\section{Conclusions}

High surface area $\mathrm{SiC}$ has been used as a support to prepare a $\mathrm{Pd} / \mathrm{SiC}$ catalyst using a liquid reduction method, and the performance of the resulting catalyst was evaluated for the carbonylative Suzuki coupling reaction of aryl iodides with arylboronic acids. Analysis of the Pd/SiC catalyst by TEM showed that homogenous Pd nanoparticles were uniformly dispersed on the SiC surface with an average particle size of $2.8 \mathrm{~nm}$. The influence of various reaction parameters, including the solvent, base, temperature, reaction time and CO pressure, were examined for the model reaction between iodobenzene and phenylboronic and the reaction condition was optimized as follows: $1.0 \mathrm{mmol}$ iodobenzene, $1.5 \mathrm{mmol}$ phenylboronic acid, $3.0 \mathrm{mmol}$ $\mathrm{K}_{2} \mathrm{CO}_{3}$ and $3 \mathrm{wt} \% \mathrm{Pd} / \mathrm{SiC}$ in $10 \mathrm{~mL}$ anisole at $100{ }^{\circ} \mathrm{C}$ under 1.0 $\mathrm{MPa}$ of $\mathrm{CO}$ pressure for $8 \mathrm{~h}$. Under the optimized conditions the conversion of iodobenzene reached up to $90 \%$ with $99 \%$ selec-

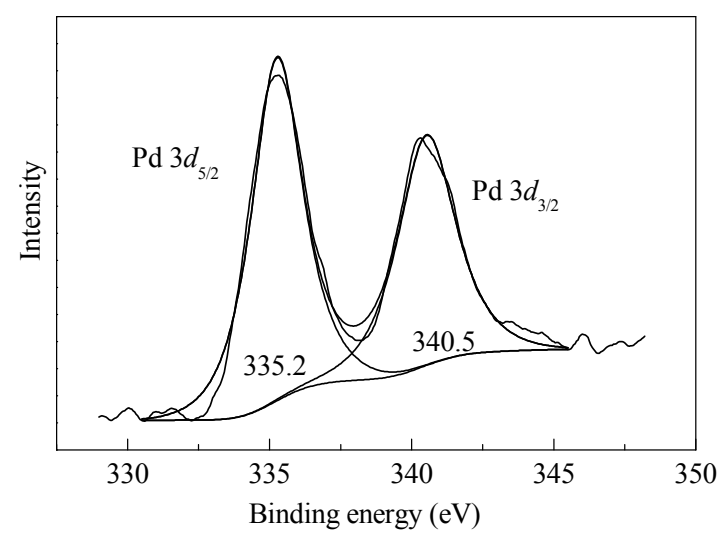

Fig. 4. XPS results for the used $\mathrm{Pd} / \mathrm{SiC}$ catalyst after five rounds. tivity towards the diphenyl ketone product. The general scope of the $\mathrm{Pd} / \mathrm{SiC}$ catalyst was also evaluated for the carbonylative Suzuki coupling reaction of a variety of different aryl iodides and arylboronic acids and found to be good. Stability experiments indicated that the decrease in the catalytic activity of the $\mathrm{Pd} / \mathrm{SiC}$ catalyst after five reaction cycles was mainly caused by the loss of the active Pd phase from the surface of the catalyst. Overall, this new heterogeneous $\mathrm{Pd} / \mathrm{SiC}$ catalyst exhibited high efficiency, high selectivity and a stable catalytic performance towards the carbonylative Suzuki coupling reaction of aryl iodides and arylboronic acids, and therefore represents an efficient and environmentally friendly approach for the synthesis of aromatic ketone.

\section{References}

[1] Wang X J, Zhang L, Sun X F, Xu Y B, Krishnamurthy D, Senanayake C H. Org Lett, 2005, 7: 5593

[2] Hatano B, Kadokaw J, Tagaya H. Tetrahedron Lett, 2002, 43: 5859

[3] Gmouh S, Yang H L, Vaultier M. Org Lett, 2003, 5: 2219

[4] Yamamoto T, Kohara T, Yamamoto A. Chem Lett, 1976, 11: 1217

[5] Hatanaka Y, Fukushima S, Hiyama T. Tetrahedron, 1992, 48: 2113

[6] Brunet J J, Chauvin R. Chem Soc Rev, 1995, 24: 89

[7] Fillion E, Fishlock D, Wilsily A, Goll J M. J Org Chem, 2005, 70: 1316

[8] Jang D 0, Moon K S, Cho D H, Kim J G. Tetrahedron Lett, 2006, 47: 6063

[9] Ishiyama T, Kizaki H, Miyaura N, Suzuki A. Tetrahedron Lett, 1993, 34: 7595

[10] Ishiyama T, Kizaki H, Hayashi T, Suzuki A, Miyaura N. J Org Chem, 1998, 63: 4726

[11] Khedkar M V, Sasaki T, Bhanage B M. RSC Adv, 2013, 3: 7791

[12] Niu J R, Liu M M, Wang P, Long Y, Xie M, Li R, Ma J T. New J Chem, 2014, 38: 1471

[13] Zhan Y Y, Cai G H, Zheng Y, Shen X N, Zheng Y, Wei K M. Acta PhysChim Sin (詹瑛瑛, 蔡国辉, 郑勇, 沈小女, 郑瑛, 魏可镁. 物理化 学学报), 2008, 24: 171

[14] Li X Y, Wang F G, Pan X L, Bao X H. Chin J Catal (李星运, 王发根, 潘秀莲, 包信和. 催化学报), 2013, 34: 257

[15] Liu H T, Li S Q, Zhang S B, Wang J M, Zhou G J, Chen L, Wang X L. Catal Commun, 2008, 9: 51

[16] Wang Y W, Guo X N, Dong L L, Jin G Q, Wang Y Y, Guo X Y. Int J Hydrogen Energy, 2013, 38: 12733

[17] Zhang G Q, Peng J X, Sun T J, Wang S D. Chin J Catal (张国权, 彭家 喜, 孙天军, 王树东. 催化学报), 2013, 34: 1745 


\title{
Graphical Abstract
}

Chin. J. Catal., 2015, 36: 322-327 doi: 10.1016/S1872-2067(14)60258-8

\section{Carbonylative Suzuki coupling reactions of aryl iodides with arylboronic} acids over Pd/SiC

Yanli Cui, Xiaoning Guo*, Yingyong Wang, Xiangyun Guo Institute of Coal Chemistry, Chinese Academy of Sciences; University of Chinese Academy of Sciences

$\mathrm{Pd} / \mathrm{SiC}$ as a heterogeneous catalyst exhibits both excellent activity and stability for the carbonylative Suzuki coupling reaction of various aryl iodides with arylboronic acids bearing different substituents.

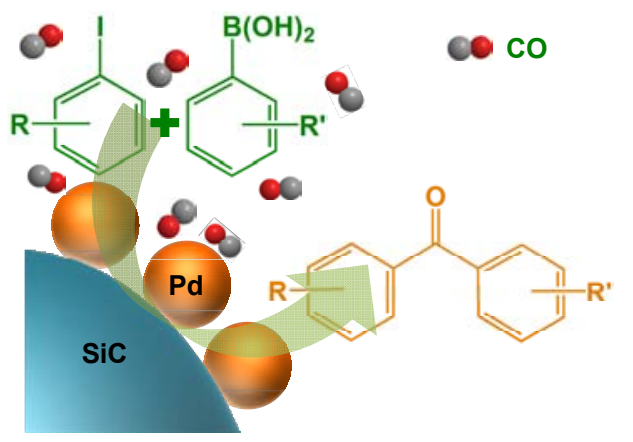

[18] Li H L, Lei Y G, Huang Y, Fang Y P, Xu Y H, Zhu L, Li X. J Nat Gas Chem, 2011, 20: 145
[19] Jiao Z F, Guo X N, Zhai Z Y, Jin G Q, Wang X M, Guo X Y. Catal Sci Technol, 2014, 4: 2494

\section{Pd/SiC催化碘代芳烃和芳基硼酸羰化Suzuki偶联反应性能}

\author{
崔艳丽 ${ }^{\mathrm{a}, \mathrm{b}}$ ，郭晓宁 ${ }^{\mathrm{a},}{ }^{*}$ ，王英勇 ${ }^{\mathrm{a}}$, 郭向云 ${ }^{\mathrm{a}}$ \\ ${ }^{\mathrm{a}}$ 中国科学院山西煤炭化学研究所煤转化国家重点实验室, 山西太原030001 \\ 中国科学院大学, 北京 100049
}

摘要: 以高比表面积碳化硅为载体, 通过液相还原法制备出 $\mathrm{Pd} / \mathrm{SiC}$ 催化剂, 并用于催化碘代芳烃和芳基硼酸着化Suzuki偶联反应. 利用X射线衍射、电感耦合等离子体质谱和高分辨透射电子显微镜等对催化剂进行了表征. 结果表明, $\mathrm{SiC}$ 表面的Pd纳米颗粒分散 均匀, 平均粒径约为 $2.8 \mathrm{~nm}$. 在优化溶剂、碱、压力和温度等反应条件后, 发现以 $3 \mathrm{mmol}$ 的 $\mathrm{K}_{2} \mathrm{CO}_{3}$ 和 $10 \mathrm{~mL}$ 苯甲醚分别为碱和溶剂, $1.0 \mathrm{mmol}$ 碘苯和 $1.5 \mathrm{mmol}$ 苯嗍酸在 $3 \mathrm{wt} \% \mathrm{Pd} / \mathrm{SiC}$ 催化剂存在的条件下, 在CO压力为 $1.0 \mathrm{MPa}$ 和 $100{ }^{\circ} \mathrm{C}$ 反应 $8 \mathrm{~h}$ 即可实现羰化偶联, 碘苯转化率为 $90 \%$, 二苯甲酮选择性为 $99 \%$. 并且, $\mathrm{Pd} / \mathrm{SiC}$ 对含有不同官能团的碘代芳烃和芳基硼酸羰化Suzuki偶联反应具有较好 的普适性. 同时, $\mathrm{Pd} / \mathrm{SiC}$ 也具有较好的稳定性, 经 5 次循环反应后, 碘苯转化率从 $90 \%$ 降至 $76 \%$; 催化剂活性降低的主要原因是活性 组分Pd在有机反应体系中的流失.

关键词: 钯/碳化硅; 羰化Suzuki偶联; 碘代芳烃; 芳基硼酸; 多相催化

收稿日期: 2014-09-14. 接受日期：2014-11-28. 出版日期: 2015-03-20.

*通讯联系人. 电话/传真: (0351)4040468; 电子信箱: guoxiaoning@sxicc.ac.cn

基金来源：国家自然科学基金(21203233); 山西省自然科学基金(2013021007-1).

本文的英文电子版由Elsevier出版社在ScienceDirect上出版(http://www.sciencedirect.com/science/journal/18722067). 